6. Мазайкіна I. О. Особистісно орієнтовані технології викладання іноземних мов. Сучасні інформачійні технології та інновачійні методики навчання в підготовиі фахівиів: методологія, теорія, досвід, проблеми. 2016. Вип. 45. С. 258-263.

DOI https://doi.org/10.30525/978-9934-588-80-8-2.11

\title{
«СУЧАСНІ НАПРЯМИ В ДОШКІЛЬНІЙ ПЕДАГОГІЦІ» У ПІДГОТОВЦІ ДОКТОРІВ ФІЛОСОФІЇ В УКРАЇНІ
}

Карпенко О. Є.

доктор педагогічних наук, професор,

професор кафедри загальної педагогіки та дошкільної освіти Дрогобиџький державний педагогічний університет імені Івана Франка

Чепіль М. М.

доктор педагогічних наук, професор, завідувач кафедри загальної педагогіки та дошкільної освіти Дрогобицький державний педагогічний університет імені Івана Франка м. Дрогобич, Україна

Метою статті $€$ обгрунтування доцільності вивчення навчальної дисципліни «Сучасні напрями в дошкільній педагогіці» здобувачами третього (освітньо-наукового) рівня вищої освіти освітньо-наукової програми «Дошкільна освіта». Підготовка фахівців у сфері дошкільної освіти у педагогічних університетах України відбувається відповідно до Закону України «Про вищу освіту» [1], «Про дошкільну освіту» [2], «Національної стратегії розвитку освіти в Україні на період до 2021 року» [3]. У Дрогобицькому державному педагогічному університеті імені Івана Франка така підготовка кадрів здійснюється на першому (бакалаврському), другому (магістерському) та третьому (освітньо-науковому) рівнях вищої освіти. У професійній підготовці особливе місце відведено вивчення фахових дисциплін. Нами запропоновано вивчення дисципліни «Сучасні напрями в дошкільній педагогіці» для здобувачів третього (освітньо-наукового) рівня вищої освіти доктор філософії [4].

Мета навчальної дисципліни - ознайомлення аспірантів з сучасними напрямами у дошкільній педагогіці (філософським напрямом, педагогікою прагматизму, неопозитивізму, екзистенціалізму, неотомізму, біхевіоризму та гуманістичною педагогікою). 
Навчальна дисципліна сприяє формуванню аспірантами низки програмних компетентностей, серед яких:

- здатність до аналізу концептуальних засад напрямів розвитку вітчизняної і зарубіжної дошкільної педагогіки, актуальних напрямів змін у змісті, формах, методах виховання і навчання дітей дошкільного віку;

- здатність оволодівати термінологією педагогічної науки та вибудовувати ієрархію наукових понять дошкільної педагогіки;

- здатність систематизувати знання, набуті на попередніх етапах вивчення психолого-педагогічних дисциплін щодо сутності дошкільної педагогіки, аксіологічності, динамічності, системності, взаємозв'язку, суспільної детермінованості та цілісності педагогічних явищ і процесів, багатогранності практичної спрямованості дошкільної педагогіки;

- здатність формувати педагогічне мислення аспірантів, здатність до аналітичного осмислення сутності педагогічних теорій сучасної дошкільної педагогіки, педагогічну позицію, педагогічний світогляд;

- здатність до формування в аспірантів досвіду самостійного i творчого аналізу, оцінки, порівняння педагогічних явищ, фактів, вміння прогнозувати розвиток сучасних напрямів дошкільної педагогіки;

- здатність стимулювати пошукову роботу в напрямку вдосконалення технологій навчання, диференціації педагогічної діяльності відповідно до розвитку сучасних напрямів у дошкільній педагогіці;

- здатність удосконалити вміння формулювати, відстоювати власну думку, активізувати самостійне критичне мислення, сприяти розвитку власної професійної позиції;

- будувати цілісний освітній процес 3 урахуванням основних закономірностей його перебігу, оцінювати власну діяльність як суб'єкта педагогічної праці, прагнути до постійного самовдосконалення; об'єктивно оцінювати власну діяльність.

Вивчення дисципліни спрямовується на формування таких програмних результатів навчання:

- аналізувати вітчизняні і зарубіжні психолого-педагогічні концепції, теорії, дослідницькі підходи до вивчення педагогічних явищ;

- вміти використовувати методи порівняльно-педагогічного дослідження;

- оперувати термінологією дошкільної педагогіки;

- планувати, організовувати, методично спрямовувати освітній процес на основі програмного змісту, з урахуванням потреб, інтересів, темпів розвитку кожної дитини, а також зарубіжного досвіду;

- впроваджувати елементи інноваційних моделей навчання у практику роботи школи;

- застосовувати отримані знання у процесі викладання у вищій школі: використовувати оптимальні форми, методи i засоби, 
спираючись на досвід організації дошкільної освіти, теоретикометодологічні концепції дошкільної педагогіки;

- розуміти історію та закономірності розвитку дошкільної освіти, аналізувати педагогічні системи минулого та творчо трансформувати їх потенціал у сучасний навчально-виховний простір закладу дошкільної освіти.

Зміст навчальної дисципліни передбачає володіння систематичними знаннями основних напрямів в дошкільній педагогіці; грунтовне визначення ролі дошкільної педагогіки в системі наукового знання, впливу філософських теорій на педагогічні концепції та виховні системи; орієнтування у теорії та методології формування світоглядних орієнтацій сучасної дитини дошкільного віку; уміння вести самостійний пошук і використовувати інформацію про виникнення та основні ідеї педагогіки прагматизму; чітко визначити провідні положення педагогічної системи Дж. Дьюї, знати особливості педагогіки прагматизму в окремих країнах світу, основні положення критичного мислення за Е. Шартьє, володіти знаннями щодо професіограми вихователя за Ш. Брю, грунтовно знати когнітивно-орієнтований курс Ж. Піаже, орієнтуватися в Інтелект-картах Т. Бьюзена, змісті та основних положеннях теорії морального розвитку Л. Кольберга, індивідуалістичній спрямованості педагогіки екзистенціалізму; орієнтуватися у поглядах педагогів-екзистенціалістів на виховання дітей, знати етичну теорію екзистенціалізму; чітко визначати роль і завдання вихователя в освітньому процесі; на високому рівні володіти концептуальними ідеями представників педагогіки екзистенціалізму (Дж. Кнеллер, У. Баррет, М. Марсель); грунтовно знати особливості виховання характеру за Г. Клаудом і Дж. Таусендом та виховання духовності за П. Дженкінс; досконало володіти знаннями щодо педагогіки неотомізму в окремих європейських країнах; чітко орієнтуватися в основних ідеях біхевіоризму як психолого-педагогічної концепції; грунтовно знати систему алгоритмів педагогічної діяльності Б. Блума; чітко знати ключові ідеї виховання талантів за С. Судзукі; досконало орієнтуватися у теоретичних основах гуманістичної педагогіки та концепції «гуманістичної освіти» в сучасній дошкільній педагогіці; на високому рівні володіти знаннями щодо основних ідей представників педагогіки серця (М. Лопаткова, В. Сухомлинський) та гуманістичної педагогіки (Ш. Амонашвілі, Я. Корчак).

Вивчення аспірантами навчальної дисципліни «Сучасні напрями в дошкільній педагогіці» сприятиме формуванню у них прагнення до постійного самовдосконалення, розуміння необхідності підвищення свого професійного рівня та педагогічної майстерності, спонукатиме до участі у науково-методичних семінарах. 


\title{
Література:
}

1. Закон України «Про вищу освіту» № 1556-VII ред. від 16.01.2020. URL: https://zakon.rada.gov.ua/laws/show/1556-18

2. Закон України «Про дошкільну освіту». № 2628-III ред. від 16.07.2019. URL: https://zakon.rada.gov.ua/laws/show/2628-14

3. Національна стратегія розвитку освіти в Україні на період до 2021 року. № 344/2013 ред. від 25.06.2013. URL: https://zakon.rada.gov.ua/ laws/show/344/2013.

4. Карпенко О., Чепіль М.М. Сучасні напрями в дошкільній педагогіці: робоча програма навчальної дисципліни для підготовки фахівців третього (освітньо-наукового) рівня вищої освіти доктора філософії. Дрогобич: Ред.-вид. відділ ДДПУ імені Івана Франка, 2020. 22 с.

DOI https://doi.org/10.30525/978-9934-588-80-8-2.12

\section{ДЕЯКІ АСПЕКТИ РОЗВИТКУ КРИТИЧНОГО МИСЛЕННЯ УЧНІВ У КОНТЕКСТІ ПОРІВНЯННЯ ЗМІСТУ ПОЧАТКОВОЇ ОСВІТИ АМЕРИКАНСЬКОЇ ТА УКРАЇНСЬКОЇ ШКОЛИ}

\author{
Кловак Г. Т. \\ доктор педагогічних наук, \\ доцент кафедри педагогіки і психологї̈ початкової освіти \\ Глухівський національний педагогічний університет \\ імені Олександра Довженка \\ Собко В. О. \\ кандидат педагогічних наук, доцент, \\ завідувач кафедри теорії і методики початкової освіти \\ Глухівський національний педагогічний університет \\ імені Олександра Довженка \\ м. Глухів, Сумська область, Украӥна
}

Сучасна педагогічна наука визначає навички критичного мислення як одні з провідних в рейтингу професійної діяльності та пристосування до життя в нових мінливих умовах. Значимість цього підтверджують практика широкого використання технологій розвитку критичного мислення молодого покоління багатьох розвинених країн світу. Зокрема, Національні стандарти США виділяють критичне мислення як важливу умову формування навичок трансформації та пристосування до сьогодення, тому у змісті навчальних програм різних 